\title{
Determining the Motives or Reasons that Make Companies Disclose Environmental Information
}

\author{
Ali Aldrugi and Hafez Abdo
}

\begin{abstract}
This paper presents an empirical investigation into environmental disclosure practices of oil and gas companies operating in Libya. It aims at exploring key motives for oil and gas companies operating in Libya for disclosing environmental information in their annual report. Hence, the paper seeks to answer the following questions: What motivate companies in Libya to disclose and pursue environmental information? In answering this question and meeting the aims of the research questionnaire method was used to collect data. Key factors were proposed based on previous studies namely: reputation, legal requirements, meeting society expectations, society pressures and economic factors. A total of 115 questionnaires were collected from 43 local and foreign companies operating in the Libyan oil and gas sector. The results indicate that foreign companies considered issues such as Reputation, Expectations of society, Legal requirements, Pressures of society and Economic factors as motives that encourage them to disclose environmental information. On the other hand the investigation refuel that local companies accept just Reputation and society Pressures of as motives that encourage them to disclose environmental information.
\end{abstract}

Index Terms-Company, disclosure, environmental, Libya, oil.

\section{INTRODUCTION}

Full disclosure is the main source of information on corporate activities for those parties interested in this information so that to assist them in the rationalization of its economic decisions [1]. Social disclosure is seen as the component within full disclosure which enables them to evaluate the extent to which the company has upheld its social responsibilities. Social disclosure attracted much interest particularly between 1970 and 1980, but since 1990, the focus has increasingly been on Environmental disclosure as one of the most important types of social disclosure [2]. Reference [3] argues that Environmental disclosure is one of the major components of social disclosure and plays a major role in meeting the needs of the users of reports and financial statements. It supplies users with information that helps them assess the efficiency of organizations when it comes to their use of economic resources and the extent to which they fulfil their environmental responsibilities. Environmental disclosure can be defined as this disclosure that relates to the impact company activities have on the physical or natural environment in which it operates [4].

However, despite the growing interest being shown in

Manuscript received March 29, 2013; revised May 29, 2013

Ali Aldrugi is with the Faculty of Economics and Commerce AlMergeb University- Libya (e-mail: N0237405@ntu.ac.uk).

Hafez Abdo is with the Nottingham Business School.
Environmental disclosure in developed countries such as the USA and the United Kingdom [5], it is much rarer elsewhere; a number of studies have shown that few developing countries show any interest in Environmental disclosure [6]-[11]. This may because environmental disclosure is more of a voluntary than mandatory activity at present. This begs the question: why do companies engage in public disclosure of their environmental performance, exposing themselves to a number of risks and bearing unnecessary costs, when they know that they are not obliged to do so? Therefore, studying and determine the motives or reasons that make companies disclose environmental information is the main incentive to conduct this study.

\section{LITERATURE REVIEW AND METHODOLOGY}

Since the second half of the twentieth century significant global attention has been paid to the issue of environmental disclosure. Many studies were conducted in order to answer the following question: why do companies disclose environmental information? Although important, these studies have not provided conclusive evidence, and there is still disagreement about issues such as companies' reasons and justifications for disclosing environmental information.

A number of these studies found that the motive was to improve companies' image and reputation before the public, especially to companies whose reputation has been damaged as a result of an accident or an environmental disaster. In this context, reference [6] concludes that firms with bad long-term environmental reputations will disclose more environmental information in their annual reports than other firms to enhance and improve their image and reputation before the public opinion. Expectations of society have also been shown to be a motivation for companies to disclose environmental information [12]-[13]. On the other hand, other studies argue that the expectations of society are largely insignificant [14]. Other investigations have examined the correlation between environmental disclosure and legal requirements. The findings indicate that companies that have been prosecuted are more likely to practise environmental disclosure in order to comply with environmental laws and regulations [15]-[16]. However reference [17] confirms that companies consider the legal requirements as having no effect on their level of disclose environmental information.

Furthermore, research reveal that companies do disclose environmental information in response to pressure from organisations interested in environmental performance and pressure groups as a whole [6]. In this context, according to reference [15] Chinese companies disclose environmental information mainly to alleviate the pressure from the 
government; in contrast the pressure from other important stakeholders like shareholders and creditors tested in this study appears to be weak. In terms of economic factors the results of empirical studies have been mixed; a number of studies support the idea of a positive relationship between profit as one of the economic factors and the extent of environmental information, while other studies have found no correlation, [15]-[18].

Although the important of prior studies in the field of social and environmental disclosure. The literature review showed that the vast majority of these studies have focused on developed countries such as Western Europe, America, and Australia; even international studies have concentrated on these countries and neglected developing countries. Even international studies have focused on these countries while neglecting the developing countries. According to many studies it is dangerous and wrong to apply the findings from these studies to developing countries [19]-[20] since environmental disclosure varies from one country to another for economic, social, political and cultural reasons [20] -[22]. Consequently, a number of writers have advocated that more research be conducted on social and environmental activities and their disclosure in developing countries [7] -[11]. Among these writers, also reference [14] called for research on the disclosure of individual social activities, especially environmental disclosure, in Libya.

The present study is a response to this lack of research on environmental disclosure in developing and newly industrialized nations, and to the current lack of consensus and/or conclusive evidence on the reasons why companies disclose their environmental information. Therefore, this study attempts, to answer the following question: What are the motives that make oil and gas companies operating in Libya disclose environmental information? To answer this question, a total of 115 questionnaires were collected from 43 local and foreign companies operating in the Libyan oil and gas sector. Descriptive statistics were used to analyze these questionnaires, if differences were found in the views of local and foreign oil companies, the Mann-Whitney test was used to test whether these differences are statistically significant or not.

\section{DATA DiscUSSION AND ANALYSIS}

This section attempts, to answer the following question: What are the motives that make oil companies operating in Libya disclose environmental information? To answer this question, some essential statements were hypothesized in line with previous studies. They are grouped into categories: reputation, legal requirements, meeting the expectations of society, society pressures and economic factors.

\section{A. Reputation}

Table I shows that the median of the answers from foreign companies for this criterion was 4.25 , with an inter-quartile score of 1 . This indicates that foreign companies strongly agreed that improving reputation is a disclosure motive, and that there was no significant difference between them in terms of their responses to this statement. Along similar lines, there is evidence that local companies also consider company reputation to be a determinant of environmental disclosure and one of the main purposes of environmental disclosure. Table I shows that the median of the answers from local companies for this element is 3.875 agree, with an inter-quartile score of 2.75.So there is variance and inconsistency in the answers of local companies about this element as a motive driving the disclosure of environmental information. This indicates that some respondents from local companies were in strong agreement, while others strongly disagreed. The disagreement of some companies is probably due to the fact that, as public companies, they do not have shareholders or shares traded on the stock market, and their reputation does not have much effect on their performance or Balance Sheet value. They are less concerned with improving their reputation and transparency than the foreign companies.

Although, company reputation yielded high median scores for both local and foreign companies and that there were no significant differences between their responses. Respondents from the foreign companies tended to agree more strongly with the importance of company reputation than did those from the local companies, but as Table I shows, the level of agreement between foreign and local companies is significant. The calculated $Z$ value is between -1.96 and +1.96 and the p-values larger than 0.05 . So there is no significant difference between two groups of companies in about companies reputation as motive that encourages them to disclose environmental information.

TABLE I: MEDiAn OF RESPONDENT’ ANSWERS ABOUT THE REPUTATION

\begin{tabular}{|c|c|c|c|c|c|}
\hline \multirow{4}{*}{ 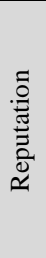 } & & $\begin{array}{c}\text { Foreign } \\
\text { companies }\end{array}$ & $\begin{array}{c}\text { Local } \\
\text { companies }\end{array}$ & \multicolumn{2}{|c|}{ Mann-Whitney } \\
\hline & Median & 4.25 & 3.875 & $\mathrm{Z}$ & p-value \\
\hline & $\begin{array}{c}\text { Inter-quartile } \\
\text { Range }\end{array}$ & 1 & 2.75 & \multirow[t]{2}{*}{-1.757} & \multirow[t]{2}{*}{0.79} \\
\hline & Scale & $\begin{array}{l}\text { strongly } \\
\text { agree }\end{array}$ & agree & & \\
\hline
\end{tabular}

\section{B. Meeting the Expectations of Society}

From Table II it can be noted that local and foreign companies differ widely on this issue. Respondents from foreign companies agreed strongly that one main purpose of corporate disclosure is to meet the expectations of society. They ranked this highly as a motive, giving it a median score of 4.25 and a very small inter-quartile score of 0.05 . This means that there is strong agreement and consistency among the foreign companies on this element.

TABLE II: MEDIAN OF RESPONDENT’ ANSWERS ABOUt MEETING THE

\begin{tabular}{|c|c|c|c|c|c|}
\hline \multicolumn{6}{|c|}{ EXPECTATIONS OF SOCIETY } \\
\hline \multirow{4}{*}{ 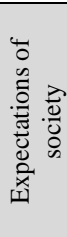 } & & $\begin{array}{c}\text { Foreign } \\
\text { companies }\end{array}$ & $\begin{array}{c}\text { Local } \\
\text { companies }\end{array}$ & \multicolumn{2}{|c|}{ Mann-Whitney } \\
\hline & Median & 4.25 & 2.375 & $\mathrm{Z}$ & p-value \\
\hline & $\begin{array}{c}\text { Inter-quartile } \\
\text { Range }\end{array}$ & 0.50 & 1.25 & \multirow[b]{2}{*}{-8.140} & \multirow{2}{*}{$<.001$} \\
\hline & Scale & $\begin{array}{c}\text { strongly } \\
\text { agree }\end{array}$ & agree & & \\
\hline
\end{tabular}

In contrast, the findings indicate that local companies are less enthusiastic; Table II shows that they attribute less significance to this driver - it has a median score of 2.375 and a low inter-quartile score of 1.25.

It is apparent that there is a significant difference between 
local and foreign companies in terms of their views on the importance of meeting the expectations of society as a motive for environmental disclosure. To see whether this difference is significant or not, the Mann-Whitney test was carried out. The results reveal that there is a significant difference between local and foreign companies at the level ( $Z$ - statistic $=-8.140, p$-value $=<.001)$; the calculated $Z$ value is below -1.96 and the $\mathrm{p}$-value is less than 0.05 . One can therefore conclude that while the foreign companies consider the need to meet society's expectations a genuine motive for disclosing environmental information, it is not considered as such by local companies. Therefore, the results provide evidence that whilst meeting the expectations of society is a key driver for foreign oil companies operating in Libya, this is not the case for local oil companies. While local companies are accountable mainly to the state, all foreign companies are private and they are accountable to stakeholders and society. It is not surprising then to see foreign companies adhering to the expectations of society while local companies pay these expectations less attention.

\section{Legal Requirements}

It can be seen from Table III that there is disagreement between local and foreign companies regarding the influence of legal requirements on environmental disclosure. The respondents from foreign companies agreed that legal requirements are a driver encouraging companies to disclose environmental information. This is indicated by a median score of 3.5, agree, and a high rate of consistency in their answers, as is evident in the low inter-quartile score of 0.75 (see Table III). This means foreign companies tended to give the same answer for this statement. Respondents from local companies, in contrast, showed a high propensity to reject the proposition that legal requirements are a motive for companies to disclose environmental information. This is confirmed by the low median score of 2.25 (see Table III). The consistency in the answers of local companies is very high; the inter-quartile score of 0.75 means there are no significant differences between the local companies on this issue.

TABLE III: MEDIAN OF RESPONDENT’ ANSWERS ABOUT THE LEGAL REQUIREMENT

\begin{tabular}{|c|c|c|c|c|c|}
\hline \multirow{4}{*}{ 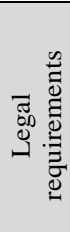 } & & Foreign & Local & \multicolumn{2}{|c|}{ Mann-Whitney } \\
\hline & Median & 3.5 & 2.25 & $\mathrm{Z}$ & p-value \\
\hline & $\begin{array}{l}\text { Inter-quartile } \\
\text { Range }\end{array}$ & 0.75 & 0.75 & \multirow{2}{*}{-6.089} & \multirow{2}{*}{$<.001$} \\
\hline & Scale & agree & disagree & & \\
\hline
\end{tabular}

The Mann-Whitney test was used to assess whether the differences between local and foreign companies in regard to this proposition are significant or not. Table III shows that the calculated $Z$ value is below -1.96 and the p-value is less than 0.05 , the results reveal that the difference between the two groups of companies on this issue is in fact significant. Although there are a number of environmental laws in Libya, local companies are under no real obligation to disclose environmental information and so do not see adherence to regulatory requirements as being a driver of environmental disclosure. However, the legal requirements are an influential driver of environmental disclosure practices among foreign companies. This may not be surprising, since foreign companies are obliged by law to disclose environmental information in their origin countries.

\section{Pressures of Society}

It can be seen from Table IV that the respondents from foreign companies tended to agree more strongly than those from the local companies that society pressure influences the amount and level of environmental disclosure, though both groups saw it as significant. It was ranked the highest by foreign companies, as confirmed by the median score of 3.75 , There was a high level of consistency among the foreign companies with regard to this statement: Table IV shows an inter-quartile score of 0.50 . In other words, foreign companies tended to give the same answer for this statement.

Society pressures were given also emphasis by local companies, with a median score of 3.625 , and an inter-quartile score of 1 . This means that all local and foreign companies tended to give the same answer for this statement. Thus, there is no significant difference between the two groups of companies in terms of their perception of the importance of society pressures in encouraging companies to disclose environmental information.

TABLE IV: MEDIAN OF RESPONDENT’ ANSWERS ABOUT THE SOCIETY PRESSURES

\begin{tabular}{|c|c|c|c|c|c|}
\hline \multirow{4}{*}{ 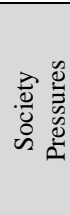 } & & Foreign & Local & \multicolumn{2}{|c|}{ Mann-Whitney } \\
\hline & Median & 3.75 & 3.625 & $\mathrm{Z}$ & p-value \\
\hline & $\begin{array}{c}\text { Inter-quartile } \\
\text { Range }\end{array}$ & 0.50 & 1 & \multirow[t]{2}{*}{-1.575} & \multirow[t]{2}{*}{0.115} \\
\hline & Scale & agree & agree & & \\
\hline
\end{tabular}

To double check there was a significant difference between the local and foreign companies, the Mann-Whitney test was used. Table IV shows that the calculated $Z$ value is between -1.96 and +1.96 and the p-values larger than 0.05 . Thus, there is no significant difference between local and foreign companies in terms of their perceptions of the role played by society pressures in motivating corporate disclosure. The results support the contention that there is a positive significant relationship between society pressures and the level of environmental disclosure, and that these pressures can be considered a key driver for local and foreign oil companies operating in Libya to disclose environmental information. This may not be surprising if we look at the activities of organizations interested in environmental performance and other pressure groups.

\section{E. Economic Factors}

When looking at Table $\mathrm{V}$ it can be noted that the majority of foreign respondents seemed to think that economic factors are an influential element on the level of environmental disclosure. Economic factors received a median score of 4 from foreign companies, with an inter-quartile score of 0.5 . In contrast, local companies tended not to support the contention that economic factors are a key reason for disclosure of environmental information, with a median score of 2.75 and a low inter-quartile score of 0.75 . Therefore the respondents of foreign companies agreed that economic 
factors are a motive that encourages companies to disclose environmental information, while local companies did not. The view among respondents from foreign companies that economic factors are a motive for disclosing environmental information is not surprising; it is consistent with the belief that environmental disclosure brings short- and long-term benefits such as increased volume of activity, expansion in investment and competitive advantage, which can increase share value (investors prefer to invest in companies that disclose and show an interest in environmental performance). The fact that the local companies downplayed the significance of economic factors may be ascribed to their being public corporations without shareholders or a presence on the stock market. Thus, these companies are not motivated to disclose environmental information by the need to maximize their economic returns.

TABLE V: MEDIAN OF RESPONDENT’ ANSWERS ABOUT THE ECONOMIC FACTORS

\begin{tabular}{|c|c|c|c|c|c|}
\hline \multirow{4}{*}{ 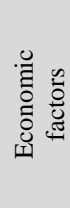 } & & Foreign & Local & \multicolumn{2}{|c|}{ Mann-Whitney } \\
\hline & Median & 4 & 2.75 & $\mathrm{Z}$ & p-value \\
\hline & $\begin{array}{c}\text { Inter-quartile } \\
\text { Range }\end{array}$ & 0.50 & 0.75 & \multirow[t]{2}{*}{-7.709} & \multirow{2}{*}{$<.001$} \\
\hline & Scale & Agree & agree & & \\
\hline
\end{tabular}

A Mann-Whitney test was carried out to understand whether the difference between local and foreign companies on this proposition is significant. Table $\mathrm{V}$ shows that the level of agreement between foreign and local companies is insignificant at the level $(Z$ - statistic $=-7.709, p$-value $=$ $<.001)$; the calculated $Z$ value is below -1.96 and the $p$-value is less than 0.05 . This means there is significant difference between the views of local and foreign companies: while the foreign companies see economic factors as having a significant impact on the level and volume of environmental disclosure, this is not the case for the local firms.

\section{CONCLUSION}

The nature and focus of the present paper was to identify the perceptions and views of local and foreign oil companies operating in Libya towards the elements that encourage companies to disclose environmental information. To achieve these objectives, some key factors were proposed based on previous studies namely: reputation, legal requirements, meeting the expectations of society, institutional pressures and economic factors.

It is observed that there is a significant difference in the view of domestic and foreign companies regarding the reasons for environmental disclosure. Our analysis indicates that the respondents of foreign companies were consistent in accepting all of the proposed reasons which may be considered as main drivers and motives that encourage companies to disclose environmental information. Therefore, significant positive associations were found between level of environmental disclosure and legal requirements, meeting the expectations of society, society pressures and economic factors, in the view of foreign companies.
In addition, the analysis above confirms that there is general agreement by local companies to accept reputation and society pressures as motives that encourage companies to disclose environmental information. Thus, local companies were satisfied with these rationales for disclosure of environmental information. On the other hand, expectations of society, legal requirements and economic factors do not have a statistically significant effect on the amount and level of environmental disclosure. The investigation did not support the hypotheses that consider these elements as significant reasons for environmental disclosure.

\section{REFERENCES}

[1] C. Marston and P. Shrives, "The use of disclosure indices in accounting research: A review article," British Accounting Review, vol. 23, no. 3 , pp. $195-210,1991$.

[2] K. Anderson, "Disclosure rules unmask pollution costs, national underwriter/property and casualty," Risk and Benefits Management, vol. 110 , no. 28 , pp. $26-27,2006$

[3] M. Akhtaruddin, "Corporate mandatory disclosure practices in bangladesh," The International Journal of Accounting, vol. 40, no. 4, pp. 399-422, 2005

[4] S. Berthelt, D. Cormier, and M. Moncton, "Environmental disclosure research: review and synthesis," Journal of Accountancy Literature, vol. 22, pp. 1-44, 2003.

[5] G. Gamble, K. Hsu, C. Jackson, and C. Tollerson, "Environmental disclosures in annual reports: an international perspective," The International Journal of Accounting, vol. 31, no. 3, pp. 293-33, 1996.

[6] J. Arevalo and D. Aravind, "Corporate social responsibility practices in India: approach, drivers, and barriers," Corporate Governance, vol. 11, no. 4, pp. 399-414, 2011.

[7] K. Babiak and S. Trendafilova, "CSR and environmental responsibility: motives and pressures to adopt green management practices," Corporate Social Responsibility and Environmental Management, vol. 18 , no. 1, pp. 11-24, 2011

[8] A. Belal and D. Owen, "The views of corporate managers on the current state of, and future prospects for, social Reporting in bangladesh," Accounting, Auditing and Accountability Journal, vol. 20, no. 3, pp. 472-494, 2007.

[9] A. Belal and S. Cooper, "The absence of corporate social responsibility reporting in Bangladesh," Critical Perspectives on Accounting, vol. 22, no. 7 , pp. 654-667, 2011.

[10] D. Jamali, "The case for strategic corporate social responsibility in developing countries," Business and Society Review, vol. 112, no. 1, pp. 1-27, 2007.

[11] F. Sobhani, A. Amran, and Y. Zainuddin, "Revisiting the practices of corporate social and environmental disclosure in Bangladesh," Corporate Social Responsibility and Environmental Management, vol. 16, no. 3, pp. 167-183, 2009.

[12] M. Tilling and C. Tilt, "The edge of legitimacy voluntary social and environmental reporting in rothmans' 1956-1999 annual reports," Accounting Auditing and Accountability Journal, vol. 23, no. 1, pp. 55-81, 2010.

[13] C. Cho and D. Patten, "The role of environmental disclosures as tools of legitimacy: A research note," Accounting, Organizations and Society, vol. 32, no. 7-8, pp. 639-647, 2007.

[14] A. Mashat, "Corporate Social Responsibility Disclosure and Accountability," Ph.D. the Manchester Metropolitan University, 2005.

[15] X. Liu and V. Anbumozhi, "Determinant factors of corporate environmental information disclosure: An empirical study of Chinese listed companies," Journal of Cleaner Production, vol. 17, no. 6, pp. 593-600, 2009

[16] C. Deegan and M. Rankin, "Do Australian companies report environmental news objectively? An analysis of environmental disclosures by firms prosecuted successfully by the environmental protection authority," Accounting, Auditing \& Accountability Journal, vol. 9, no. 2, pp. 50-67, 1996.

[17] A. shwerf, "Stakeholders' requirements and perceptions of corporate environmental disclosure in Libya," Ph.D. University of Salford, 2012.

[18] R. Gray and J. Bebbington, Accounting for the Environment, 2ed, London: SAGE, 2001.

[19] S. Gao, S. Heravi, and J. Xiao, "Determinants of corporate social and environmental reporting in Hong Kong: a research note," Accounting Forum, vol. 29, no. 2, pp. 233-242, 2005. 
[20] E. Tsang, "A longitudinal study of corporate social reporting in Singapore," Accounting Auditing and Accountability Journal, vol. 11, no. 5, pp. 624-635, 1998

[21] H. Elnaby, R. Epps, and A. Said, "The impact of environmental factors on accounting development," Critical Perspectives on Accounting, vol. 14, no. 3, pp. 273-292, 2003.

[22] N. Saleh, "Corporate environmental disclosure in Libya," Ph.D. Napier University, 2004

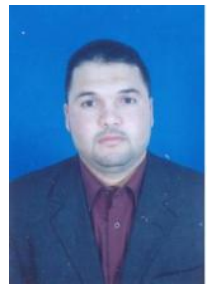

Ali Aldrugi was born on December 9, 1970 in Libya He got his master of accountancy, academy of postgraduates in Tripoli, Libya in 2004, and Ph.D in accounting in Nottingham Trent University, United Kingdom in 2013. His published articles are "Investigating the Development of Environmental Disclosures by Oil and Gas Companies Operating in Libya: a comparative study, (2012)" in the International Journal of Economics and Finance Studies, vol. 4, no. 2, pp. 1309-8055, and "Do Companies Characteristics Play Key Roles in the Level if Their Environmental Disclosure, (2012)" in Energy Research Journal, vol. 3, no. 1, pp. 1-11. 